\title{
FORMULATION AND SOME BIOLOGICAL USES OF A BUFFER MIXTURE WHOSE BUFFERING CAPACITY IS RELATIVELY INDEPENDENT OF pH IN THE RANGE pH 4-9
}

\section{DOUGLAS B. KELL and J. GARETH MORRIS}

Department of Botany and Microbiology, University College of Wales, Penglais, Aberystwyth, Dyfed SY23 3DA, U.K.

(Received 14 December 1979; accepted 4 April 1980)

A mixture is described which has a buffering capacity which is essentially independent of $\mathrm{pH}$ in the range $\mathrm{pH} 4.0-9.0$. It is shown how this buffer mixture may be used to determine the force-flux relationship of proton transfer between two aqueous phases separated by a phospholipid bilayer in vesicular systems and so demonstrate that this relationship is linear over a wide range of $\Delta \widetilde{\mu}_{\mathrm{H}^{+}}$. The buffer mix ture can, furthermore, be employed to determine the volume enclosed within a vesicular preparation.

Key words: proton transfer; $\mathrm{pH}$-independent buffering capacity; internal volume; forceflux relationship.

\section{INTRODUCTION}

The chemiosmotic theory of biological energy transduction (e.g. $[1-6])$ has aroused great interest in the role and nature of proton gradients in biochemical energy coupling. There are consequently several experimental situations in which it would be desirable to have available a buffer whose protonbuffering capacity is essentially independent of $\mathrm{pH}$ over a wide range of $\mathrm{pH}$ values. Yet inspection of the literature reveals that whilst buffer mixtures have been described, such as those of Britton and Robinson, Mcllvaine or S $\phi$ rensen [7], which exhibit strong buffering power over various $\mathrm{pH}$ ranges, none has thus far been reported whose buffering capacity is essentially independent of $\mathrm{pH}$ over a wide span of $\mathrm{pH}$ values of physiological interest. It is the purpose of this communication to describe the formulation and properties of such a buffer mixture and to illustrate its utility in the study of proton transfer processes in multi-compartment systems. It is further shown that the buffer may be exploited to determine the volume enclosed by a vesicular preparation.

\section{MATERIALS AND METHODS}

\section{Determination of $p H$}

All pH measurements were made using an Orion Model 901 Microproces- 
sor Ionalyser (MSE Scientific Instruments, Crawley, Sussex, U.K.) with a Russell $\mathrm{pH}$ electrode (impedance less than $20 \mathrm{M} \Omega$ ) and an Orion doublejunction reference electrode, in a reaction vessel thermostatted at $25^{\circ} \mathrm{C}$. This $\mathrm{pH}$ meter was accurate to $\pm 0.001 \mathrm{pH}$ units. The output from the meter was directed both in analogue form to a potentiometric chart recorder (Servoscribe Model 1s, Smiths Industries, Wembley, Middlesex, U.K.) and in binary-coded decimal form, twice per second, to a SWTPC MP68 Microcomputer. The microcomputer, its interface to the Ionalyser and a version of an interpreted BASIC called BASICION were supplied by M. James, Research Resources Ltd, 40 Stonehills, Welwyn Garden City, Hertfordshire, U.K., from whom further details may be obtained. All programs were written by the authors in BASICION. Output from the Ionalyser was stored on a minifloppy disc for subsequent retrieval and data analysis.

\section{Preparation of phospholipid vesicles}

Soybean lecithin $(480 \mathrm{mg})$ and sodium cholate $(20 \mathrm{mg})$ in $10 \mathrm{ml}$ of a tenfold dilution of stock KM3 buffer (Table 1) were sonicated for $5 \mathrm{~min}$ at room temperature using an MSE Sonicator operating at high power (150 W) and an amplitude, peak-to-peak, of $5 \mu$. The final temperature was within the range $30-40^{\circ} \mathrm{C}$. The dispersed phospholipid/cholate mixture was dialysed for a total of $30 \mathrm{~h}$ at $37^{\circ} \mathrm{C}$ against $3 \times 500-\mathrm{ml}$ vols. of the tenfolddiluted $\mathrm{KM} 3$ buffer fortified with $2.5 \mathrm{mM} \mathrm{MgCl}_{2}$. The resultant vesicular preparation was used without further purification.

\section{TABLE 1}

Composition of the stock solution of Buffer KM3

The stock solution ( $\mathrm{pH} \approx 3.5$ ) was adjusted to the desired $\mathrm{pH}$ with $\mathrm{HCl}$ or $\mathrm{KOH}$.

\begin{tabular}{lrr}
\hline Substance & Molarity & $\begin{array}{c}\text { g/l stock } \\
\text { solution }\end{array}$ \\
\hline Malonic acid & & 4.164 \\
DL-Malic acid & $40 \mathrm{mM}$ & 10.097 \\
Dipotassium oxalate & $75 \mathrm{mM}$ & 13.296 \\
Tripotassium citrate & $80 \mathrm{mM}$ & 7.66 \\
Maleic acid & $25 \mathrm{mM}$ & 8.768 \\
Disodium- $\beta$-glycerophosphate & $75 \mathrm{mM}$ & 7.65 \\
Dipotassium hydrogen phosphate & $25 \mathrm{mM}$ & 17.43 \\
$N$-2-Hydroxyethylpiperazine- $N^{\prime}-2$-ethanesulphonate & $100 \mathrm{mM}$ & 9.53 \\
Triethanolamine hydrochloride & $40 \mathrm{mM}$ & 4.64 \\
Tris(hydroxymethyl)methylglycine & $25 \mathrm{mM}$ & 13.94 \\
Glycylglycine & $75 \mathrm{mM}$ & 13.21 \\
2-Amino,2-methyl-propanediol & $100 \mathrm{mM}$ & 2.628 \\
Sodium metaborate & $25 \mathrm{mM}$ & 11.029 \\
2-Amino,2-methyl-propanol & $80 \mathrm{mM}$ & 9.42 \\
\hline
\end{tabular}




\section{Chemicals}

All chemicals were obtained from the Sigma Chemical Co., Poole, Dorset, U.K. or B.D.H. Chemicals, Poole, Dorset, U.K. and were of the highest quality available. Water was double-distilled in an all-glass apparatus.

\section{RESULTS}

Formulation of the buffer, and pH-dependence of its buffering capacity

Though the test ingredients of the buffer mixture were first selected on theoretical grounds, ionic strength effects rendered it impossible to optimise the mixture, with respect to the $\mathrm{pH}$-independence of its buffering powers, by recourse solely to calculations based on concentration and $\mathrm{p} K_{\mathrm{a}}$ values. Further improvement was achieved by semi-empirical adjustments of the concentrations of the components, leading eventually to the mixture, designated KM3, described in Table 1. This stock solution was hereafter diluted tenfold for all experiments. The buffering capacity of the tenfold-diluted KM3 mixture over the range of $\mathrm{pH}$ values of greatest interest to biochemists is shown in Fig. 1. Though the buffering capacity is not entirely independent of $\mathrm{pH}$ over the range $\mathrm{pH} 4-9$, the maximum variation about the median buffering capacity is only $12 \%$.

Determination of force-flux relations for $H^{+}$transfer across liposomes

Mitchell and Moyle [8] demonstrated that, in contrast to what one might perhaps have expected, topologically closed biological membrane systems are

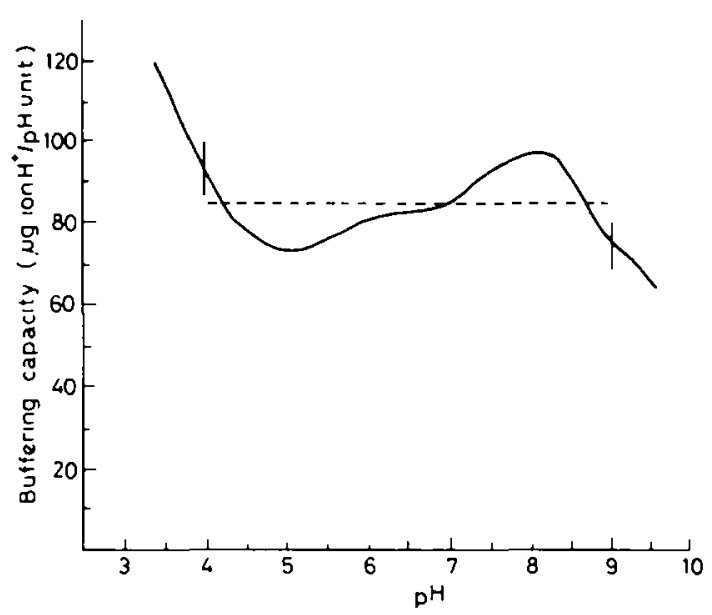

Fig. 1. Effect of $\mathrm{pH}$ on buffering capacity of Buffer KM3. A tenfold-diluted sample of Buffer KM3 (Table 1) was adjusted to $\mathrm{pH} \mathrm{9.8} \mathrm{with} \mathrm{KOH.} \mathrm{Microlitre} \mathrm{volumes} \mathrm{of} 10 \mathrm{M} \mathrm{HCl}$ were added to a $6 \mathrm{ml}$ volume of sample such that the $\mathrm{pH}$ excursion was approximately $0.06 \mathrm{pH}$ units, and the buffering capacity was calculated from the relation $B=-\delta \mathrm{H}^{+}$l $\delta \mathrm{pH}$. 
rather impermeable to protons. Thus, when a weakly buffered suspension of mitochondria was challenged with a pulse of acid sufficient to change the $\mathrm{pH}$ measured with a macroscopic glass electrode by approximately $0.05-0.1 \mathrm{pH}$ units, the response of the $\mathrm{pH}$ electrode could be subdivided into two parts: a rapid acidification of the medium occurring faster than the response time of the $\mathrm{pH}$ electrode, $\left(t_{1 / 2}=\mathrm{ca} .1 \mathrm{~s}\right)$, followed by a slower $\left(t_{1 / 2}=70-90 \mathrm{~s}\right)$ and smaller alkalinisation. These phenomena were correctly ascribed to the titration of two kinetically distinct compartments separated by a relatively proton-impermeable osmotic barrier (the $M$ phase). It was initially assumed, and subsequently demonstrated [8], that the rate of proton transfer across the $\mathrm{M}$ phase was linearly related to the concentration gradient of protons $\vec{\Delta} \mathrm{pH}$ across the barrier $\mathrm{M}$ phase for $\vec{\Delta} \mathrm{pH}$ values less than $0.1 \mathrm{pH}$ units. The buffering capacities of the outer (rapidly-titrating) and inner (more slowly titrating) aqueous phases are given [8] by the equations

$B_{\mathrm{O}}=-\Delta \mathrm{H}^{+} / \Delta \mathrm{pH}_{0}^{\alpha}$

$B_{\mathrm{T}}=-\Delta \mathrm{H}^{+} / \Delta \mathrm{pH}_{0}^{\omega}$

$B_{\mathrm{i}}=B_{\mathrm{T}}-B_{\mathrm{O}}$

where $\Delta \mathrm{H}^{+}$is the quantity of $\mathrm{H}^{+}$added to the system, $B_{\mathrm{O}}, B_{\mathrm{T}}$ and $B_{\mathrm{I}}$ refer to the buffering capacities of the outer, total (inner plus outer) and inner phases, respectively, and the meaning of $\Delta \mathrm{pH}_{0}^{\alpha}$ and $\Delta \mathrm{pH}_{0}^{\omega}$ is given in Fig. 2. In view of the present interest in the force-flux relationships of protonmotive systems (e.g. [9-13]), we decided to determine the relationship between the rate of $\mathrm{H}^{+}$transfer and $\mathrm{pH}$ gradient across the $\mathrm{M}$ phase of such systems when $\overrightarrow{\mathrm{p} H}$ is much greater than 0.1 The method relies upon the ability to calculate the internal $\mathrm{pH}$ of such vesicular systems using the knowledge that the buffering capacity of the inner phase is essentially independent of $\mathrm{pH}$. The terminology used for describing this type of experiment is given in Fig. 2, where changes in a given phase are prescribed by the operator $\Delta$, whilst differences between phases are denoted by $\vec{\Delta}$ (cf. [8]). If the starting

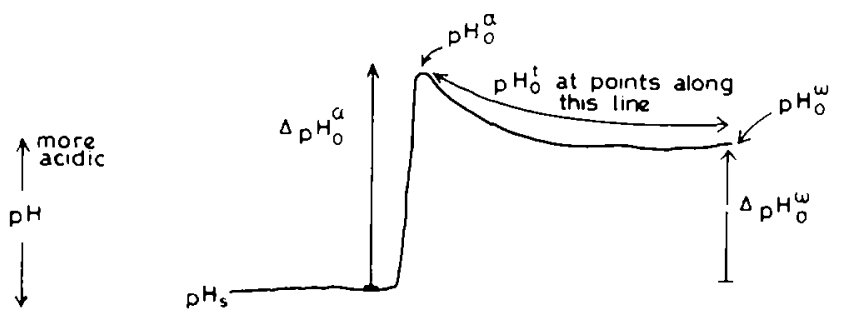

Fig. 2. Terminology used in describing an acid-pulse experiment. 'The figure shows the different phases of an acid-pulse experiment as described in the text, and diagrammatically, the direction of the $\mathrm{pH}$ changes encountered in such an experiment. 
$\mathrm{pH}$ is $\mathrm{pH}_{\mathrm{s}}$ and the initial and final $\mathrm{pH}$ excursions following the acid pulse are $\Delta \mathrm{pH}_{0}^{\alpha}$ and $\Delta \mathrm{pH}_{0}^{\omega}$ (Fig. 2), then knowing the quantity of $\mathrm{H}^{+}$added, we may calculate the internal and external buffering capacities from Eqns. 1-3. If these quantities are known to be independent of $\mathrm{pH}$, we may then calculate the internal $\mathrm{pH}$ over the time of the decay of the acid pulse across the $\mathrm{M}$ phase. The boundary conditions are that at $t=0, \mathrm{pH}_{\mathrm{I}}=\mathrm{pH}_{\mathrm{S}}$ and $\mathrm{pH}_{\mathrm{O}}=$ $\mathrm{pH}_{0}^{\alpha}$, and that at $t=\infty, \mathrm{pH}_{\mathrm{I}}=\mathrm{pH}_{\mathrm{O}}$. Thus, at any point on the decay curve we may obtain the number of protons that have moved across the membrane from the relationship

$\delta \mathrm{H}^{+}=\left(\mathrm{pH}_{0}^{\alpha}-\mathrm{pH}_{0}^{\mathrm{t}}\right) / B_{\mathrm{O}}$

Since these protons must appear inside the vesicles we may thus obtain the intravesicular $\mathrm{pH}$ from the equation

$\mathrm{pH}_{\mathrm{I}}=\mathrm{pH}_{\mathrm{S}}+\left(\mathrm{pH}_{0}^{\mathrm{t}}-\mathrm{pH}_{0}^{\alpha}\right) \times\left(B_{\mathrm{I}} / B_{\mathrm{o}}\right)$

$\vec{\Delta} \mathrm{pH}$ at any point on the curve is obviously given by the relationship $\vec{\Delta} \mathrm{pH}=$ $\mathrm{pH}_{\mathrm{I}}-\mathrm{pH}_{\mathrm{O}}$ whilst the rate of $\mathrm{H}^{+}$transfer may be obtained from the slope of a plot of $-\ln \left(\mathrm{pH}_{0}^{\omega}-\mathrm{pH}_{0}^{\mathrm{t}}\right)$ versus time. Thus we may determine the $\mathrm{pH}$ gradient and force-flux relationship at any point on the decay curve using measurements of the external $\mathrm{pH}$ alone.

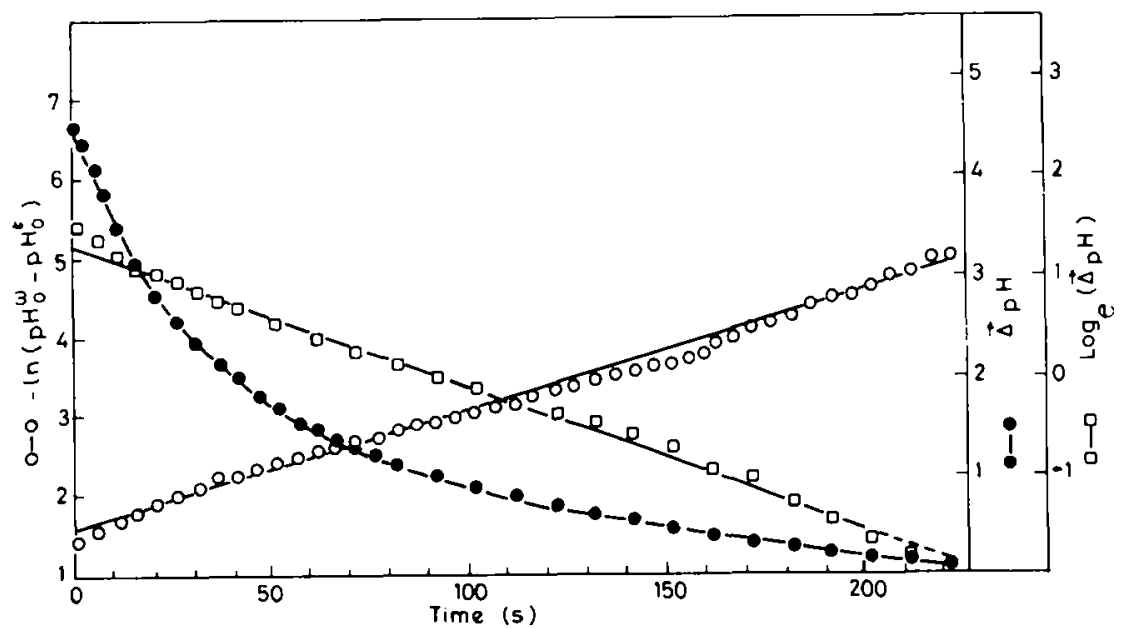

Fig. 3. Secondary plot of various parameters of an acid-pulse experiment performed using the KM3 Buffer. The reaction mixture contained $6 \mathrm{ml}$ of a suspension of phospholipid vesicles $(20 \mathrm{mg}$ phospholipid $/ \mathrm{ml}$ ) and $128 \mu \mathrm{g}$ carbonic anhydrase in tenfold-diluted $\mathrm{KM} 3$ Buffer $(\mathrm{pH}=8.712)$ prepared as described in Materials and Methods. At $t=-2 \mathrm{~s}, 42 \mu \mathrm{l}$ of $10 \mathrm{M} \mathrm{HCl}$ were added to bring the $\mathrm{pH}$ to 4.16 , and the subsequent decay of $\mathrm{pH}_{0}$ was followed as described in Materials and Methods. Data storage and the calculation of $\triangle \mathrm{pH}$ was performed, as described in the text, by the microcomputer. 
Fig. 3 shows the results of a typical acid pulse experiment of the type described above, in which $\Delta \mathrm{pH}_{0}^{\alpha}$ (and thus, of course, $\vec{\Delta} \mathrm{pH}$ ) was made to exceed 4 units. From many experiments of this type, the following general conclusions could be drawn (cf. Fig. 3):

(a) For values of $\vec{\Delta} \mathrm{pH}$ between 0.1 and 4.5 the rate of decay of $\mathrm{H}^{+}$across the $M$ phase of the phospholipid vesicles is accurately described by a single exponential equation; in other words, the relationship between $\Delta \widetilde{\mu}_{\mathrm{H}^{+}}$and the rate of $\mathrm{H}^{+}$translocation was linear even at values of the transmembrane electrochemical proton gradient far removed $(>250 \mathrm{mV})$ from equilibrium.

(b) Under conditions of a $\mathrm{pH}$-independent buffering capacity of the two phases, $\vec{\Delta} \mathrm{pH}$ also decayed in an exponential fashion.

(c) The lack of dependence on $\mathrm{pH}$ of the rate of passage of $\mathrm{H}^{+}$across the vesicular $M$ phase indicated that no significant transmembrane $\mathrm{H}^{+}$transfer was effected by the penetration across the membrane of any of the buffer components in its uncharged form.

(d) Under the present conditions the osmotic volume enclosed by the vesicle preparation may be accurately obtained from the relationship

Internal volume fraction (in $\mathrm{ml}$ per $\mathrm{ml}$ reaction mixture) $=\frac{\text { Inner volume }}{\text { Total volume }}$

$=\frac{\Delta \mathrm{pH}_{0}^{\alpha}-\Delta \mathrm{pH}_{0}^{\omega}}{\Delta \mathrm{pH}_{0}^{\alpha}}$

Under conditions in which the buffering capacity of the system per se, relative to that of the added buffer, is not insignificant, the enclosed volume fraction is equal to the ratio of the slopes of plots of the measured $B_{\mathrm{I}}$ and $B_{\mathrm{T}}$ versus the added buffer concentration.

\section{DISCUSSION}

In a number of recent studies (e.g. $[14,15])$ of the protonic coupling mechanism of electron transport phosphorylation, it has been assumed that the force-flux relationship between $\Delta \tilde{\mu}_{\mathrm{H}^{+}}$and the rate of transmembrane $\mathrm{H}^{+}$ transfer is a linear one even at rather high values of $\Delta \tilde{\mu}_{\mathrm{H}^{+}}$. The present analysis shows that this assumption may be regarded as correct, provided that the coupling protons are osmotically active, a view which is not universally held $[5,9-11,13,16]$. The present system should be of value in testing the view that the proton channel of the $F_{0} F_{1}$-ATPase has rather special currentvoltage properties as regards its protonophoric activity (e.g. [17-19]). Finally, we would mention that the present buffer system has proved useful as a supporting electrolyte in polarographic studies [20]; it may also find utility in isoelectric focussing systems of the type described by Prestidge and Hearn [21]. 


\section{SIMPLIFIED DESCRIPTION OF THE METHOD AND ITS APPLICATIONS}

The multicomponent buffer mixture whose formulation is described in this paper demonstrates a buffering capacity which is relatively independent of $\mathrm{pH}$ in the range $\mathrm{pH}$ 4-9. It has been employed to demonstrate that the force-flux relationship of proton transfer between two aqueous phases separated by a phospholipid bilayer in vesicular systems is linear over a wide range of $\Delta \tilde{\mu}_{H^{+}}$. It has further been shown how this buffer mixture can be exploited to determine the volume enclosed within such a vesicular preparation. The buffer mixture has proved useful as a supporting electrolyte in polarographic studies and is also likely to prove most valuable in isoelectric focussing procedures and a variety of biochemical assays.

\section{ACKNOWLEDGEMENTS}

We are indebted to the Science Research Council, U.K., for generous financial support, and to Mike James, Research Resources Ltd., for his invaluable assistance with instrumentation.

\section{REFERENCES}

1 Mitchell, P. (1966) Bjol. Rev. Cambridge Phil. Soc. 41, 445-502

2 Mitchell, P. (1976) Biochem. Soc. Trans. 4, 399-430

3 Mitchell, P. (1977) FEBS Lett. 78, 1-20

4 Harold, F.M. (1972) Bacteriol. Rev. 36, 172-230

5 Boyer, P.D., Chance, B., Ernster, L., Mitchell, P., Racker, E. and Slater, E.C. (1977) Annu. Rev. Biochem. 46, 955-1026

6 Haddock, B.A. and Hamilton, W.A., eds. (1977) Symp. Soc. Gen. Microbiol. 27, $1-423$

7 Perrin, D.D. and Dempsey, B. (1974) Buffers for pH and Metal Ion Control. Chapman and Hall, London

8 Mitchell, P. and Moyle, J. (1967) Biochem. J. 104, 588-600

9 Baccarini-Melandri, A., Casadio, R. and Melandri, B.A. (1977) Eur. J. Biochem. 78, $389-402$

10 Azzone, G.F., Pozzan, T., Viola, E. and Arslan, P. (1978) Biochim. Biophys. Acta, $501,317-329$

11 Rottenberg, H. (1978) in Progress in Surface and Membrane Science (Danielli, J.F., Cadenhead, A. and Rosenberg, M.D., eds.), Vol. 12, pp. 245-325. Academic Press, New York

12 Nicholls, D.G. (1979) Biochim. Biophys. Acta, 549, 1-29

13 Kell, D.B. (1979) Biochim. Biophys. Acta 549, 55-99

14 Brand, M.D., Harper, W.G., Nicholls, D.G. and Ingledew, W.J. (1978) FEBS Lett. 95, $125-129$

15 Wikström, M. and Krab, K. (1979) Biochim. Biophys. Acta 549, 177-222

16 Williams, R.J.P. (1978) Biochim. Biophys. Acta 505, 1-44

17 Pansini, A., Guerrieri, F. and Papa, S. (1978) Eur. J. Biochem. 92, 554-551

18 Ho, Y.-K. and Wang, J.H. (1979) Biochem. Biophys. Res. Commun. 89, 294-299

19 Slooten, L. and Branders, C. (1979) Biochim. Biophys. Acta, 547, 79-90

20 Kell, D.B. and Morris, J.G. (1979) FEBS Lett., in press

21 Prestidge, R.L. and Hearn, M.T.W. (1979) Anal. Biochem. 97, 95-1.02 
NOTE ADDED IN PROOF (Received 11 August 1980)

Following earlier work (Hellingwerf, K.J. (1979) Thesis, University of Amsterdam), Arents, van Dekken, Hellingwerf and Westerhoff (Westerhoff, H.V., personal communication) have also employed a buffer mixture of the present type, which possesses a buffering

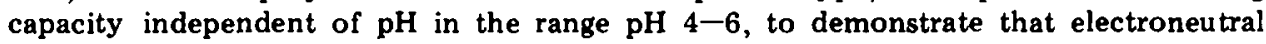
proton flux across bacteriorhodopsin-containing liposomes depends linearly upon the $\mathrm{pH}$ gradient, in line with a previous assumption (Westerhoff, H.V., Scholte, B.J. and Hellingwerf, K.J. (1979) Biochim. Biophys. Acta 547, 544-560). 